\title{
Disease dynamics of Porites bleaching with tissue loss: prevalence, virulence, transmission, and environmental drivers
}

\author{
M. Sudek ${ }^{1,4}$, G. J. Williams², C. Runyon ${ }^{3}$, G. S. Aeby ${ }^{3}$, S. K. Davy ${ }^{1, *}$ \\ ${ }^{1}$ School of Biological Sciences, Victoria University of Wellington, PO Box 600, Wellington 6140, New Zealand \\ ${ }^{2}$ Center for Marine Biodiversity \& Conservation, Scripps Institution of Oceanography, La Jolla, California 92083, USA \\ ${ }^{3}$ Hawaii Institute of Marine Biology, University of Hawaii, PO Box 1346, Kaneohe, Hawaii 96744, USA \\ ${ }^{4}$ Present address: Division of Marine and Wildlife Resources, PO Box 3730, Pago Pago 96799, American Samoa
}

\begin{abstract}
The prevalence, number of species affected, and geographical extent of coral diseases have been increasing worldwide. We present ecological data on the coral disease Porites bleaching with tissue loss (PBTL) from Kaneohe Bay, Oahu (Hawaii, USA), affecting P. compressa. This disease is prevalent throughout the year, although it shows spatio-temporal variability with peak prevalence during the warmer summer months. Temporal variability in disease prevalence showed a strong positive relationship with elevated water temperature. Spatially, PBTL prevalence peaked in clearer waters (lower turbidity) with higher water flow and higher densities of parrotfish, together explaining approximately $26 \%$ of the spatial variability in PBTL prevalence. However, the relatively poor performance of the spatial model suggests that other, unmeasured factors may be more important in driving spatial prevalence. PBTL was not transmissible through direct contact or the water column in controlled aquaria experiments, suggesting that this disease may not be caused by a pathogen, is not highly infectious, or perhaps requires a vector for transmission. In general, PBTL results in partial tissue mortality of affected colonies; on average, onethird of the tissue is lost. This disease can affect the same colonies repeatedly, suggesting a potential for progressive damage which could cause increased tissue loss over time. P. compressa is the main framework-building species in Kaneohe Bay; PBTL therefore has the potential to negatively impact the structure of the reefs at this location.
\end{abstract}

KEY WORDS: Porites compressa · Tissue mortality $\cdot$ Branching coral · Framework species $\cdot$ Coral reef ecology $\cdot$ Etiology $\cdot$ Coral disease $\cdot$ Water temperature

\section{INTRODUCTION}

Diseases have the potential to severely alter the structure and function of marine ecosystems (Ward \& Lafferty 2004). In some species, such as the longspined sea urchin in the Caribbean (Lessios 1988) and the abalone in California, USA (Lafferty \& Kuris 1993), infectious diseases have reduced population densities to such an extent that recovery is uncertain (Lafferty et al. 2004). The same is true for coral dis- eases. Coral disease outbreaks have caused declines in coral cover in many reef systems (Nugues 2002, Croquer et al. 2005, Bruckner \& Hill 2009). For example, disease outbreaks in the Caribbean have caused a severe reduction in the abundance of the 2 previously most abundant hard corals, Acropora palmata and A. cervicornis, causing a shift in the reef community structure (Gladfelter 1982, Aronson \& Precht 2001, Patterson et al. 2002). Even though the IndoPacific appears to be less affected by coral diseases 
than the Caribbean, an increasing amount of evidence suggests that coral diseases are common (Sutherland et al. 2004, Willis et al. 2004, Raymundo et al. 2005), even at remote, uninhabited islands (Williams et al. 2008, 2011b, Vargas-Angel 2009), with the types of diseases and their prevalence varying across multiple spatial scales (Aeby et al. $2011 \mathrm{a}, \mathrm{b})$. In fact, the geographical extent, number of species affected, and incidence of new diseases are increasing globally (Harvell et al. 1999, Ward \& Lafferty 2004, Sokolow 2009). Environmental stress, shifts in virulence of existing pathogens, introduction of novel pathogens from anthropogenic activities, and global climate change are associated with this increase (Harvell et al. 1999, 2004, Sokolow 2009).

Coral disease prevalence can be expected to show intricate interactions with a variety of driving factors (Williams et al. 2010, 2014). For example, an increase in temperature can lead to an increase in pathogen virulence or cause stress to the host, which can increase its susceptibility to disease (Harvell et al. 2002). Coral disease outbreaks and increases in disease prevalence and progression have been linked to various environmental factors (e.g. Bruno et al. 2003, 2007, Sato et al. 2009, Williams et al. 2010, Aeby et al. $2011 b)$. It is likely that several environmental factors simultaneously influence disease dynamics within a system, with the relative importance of each factor varying among regions, spatial scales, and species (Aeby et al. 2011a,b). We have just begun to understand the complex web of interactions between environmental factors and disease prevalence exemplified by studies that applied a multi-factor approach to studying coral disease dynamics (e.g. Bruno et al. 2007, Haapkylä et al. 2007, McClanahan et al. 2009, Williams et al. 2010, 2014, Aeby et al. 2011a,b).

Additionally, different coral diseases can show varying levels of ecological impact. For example, black band disease (BBD) and white syndromes often cause severe colony mortality (Edmunds 1991, Bruckner et al. 1997, Roff et al. 2006, Aeby et al. 2010, Williams et al. 2011a), whereas corals with Porites ulcerative white spot syndrome (PUWS) in the Philippines often show complete recovery after infection (Kaczmarsky 2006). In addition, different coral species/taxa appear to vary in their susceptibility to disease infection. For example, on the Great Barrier Reef (GBR), BBD affects 25 out of approximately 350 hard coral species, with branching Acropora spp. being most affected (Page \& Willis 2006). The degree of damage to the ecosystem therefore depends on the suite of coral species and diseases that occur on the reef. If we are to successfully manage our reef sys- tems, it is vital to understand the often intricate disease-environment interactions that lead to complex temporal and spatial disease dynamics, as well as the nature and causes of the different diseases that affect a system.

Kaneohe Bay in Oahu, Hawaii (USA), contains many fringing and patch reefs with high coral cover. Porites compressa and Montipora capitata are the 2 dominant framework-building corals on these reefs, with $P$. compressa accounting for up to $80 \%$ of the hard coral cover at some sites (Williams et al. 2010). Several coral diseases have been reported from Kaneohe Bay, of which Porites trematodiasis (Aeby 2007, Williams et al. 2010), Porites growth anomalies (Domart-Coulon et al. 2006, Williams et al. 2010, Stimson 2011), and Montipora white syndrome (MWS) (Aeby et al. 2010, Williams et al. 2010) are the most studied. In the present study, we describe the dynamics of another disease in Kaneohe Bay, Porites bleaching with tissue loss (PBTL), which affects $P$. compressa. This disease manifests as bleaching of the coenenchyme with the polyps remaining brown, giving the coral a 'speckled' appearance (Fig. 1B) which is distinct from the uniform color loss associated with thermal bleaching. PBTL causes tissue loss due to necrosis and tissue fragmentation (Sudek et al. 2012b), and a significant reduction in gamete development (Sudek et al. 2012a). Preliminary observations of an apparent increase of PBTL prevalence during the summer months suggested a potential link to temperature (M. Sudek unpubl. data), but overall little is known about the ecology of this disease. The objectives of the present study were therefore to (1) examine the variability in disease prevalence (proportion of individuals affected) over the course of $1 \mathrm{yr}$ (temporal variability), and determine the spatial distribution of PBTL within Kaneohe Bay and Hanauma Bay (another reef with high P. compressa cover located on the windward side of Oahu); (2) examine virulence (degree of harm to the host); (3) investigate disease transmissibility; and (4) determine the environmental correlates of variations in disease prevalence.

\section{MATERIALS AND METHODS}

\section{Prevalence and spatial distribution}

Prevalence surveys were conducted at 8 permanent sites (A-D and $\mathrm{G}-\mathrm{J}$ ) around Coconut Island Marine Reserve (CIMR), Kaneohe Bay, Oahu, Hawaii, USA $\left(21^{\circ} 26^{\prime} \mathrm{N}, 157^{\circ} 47^{\prime} \mathrm{W}\right.$; Fig. 2), on an ap- 


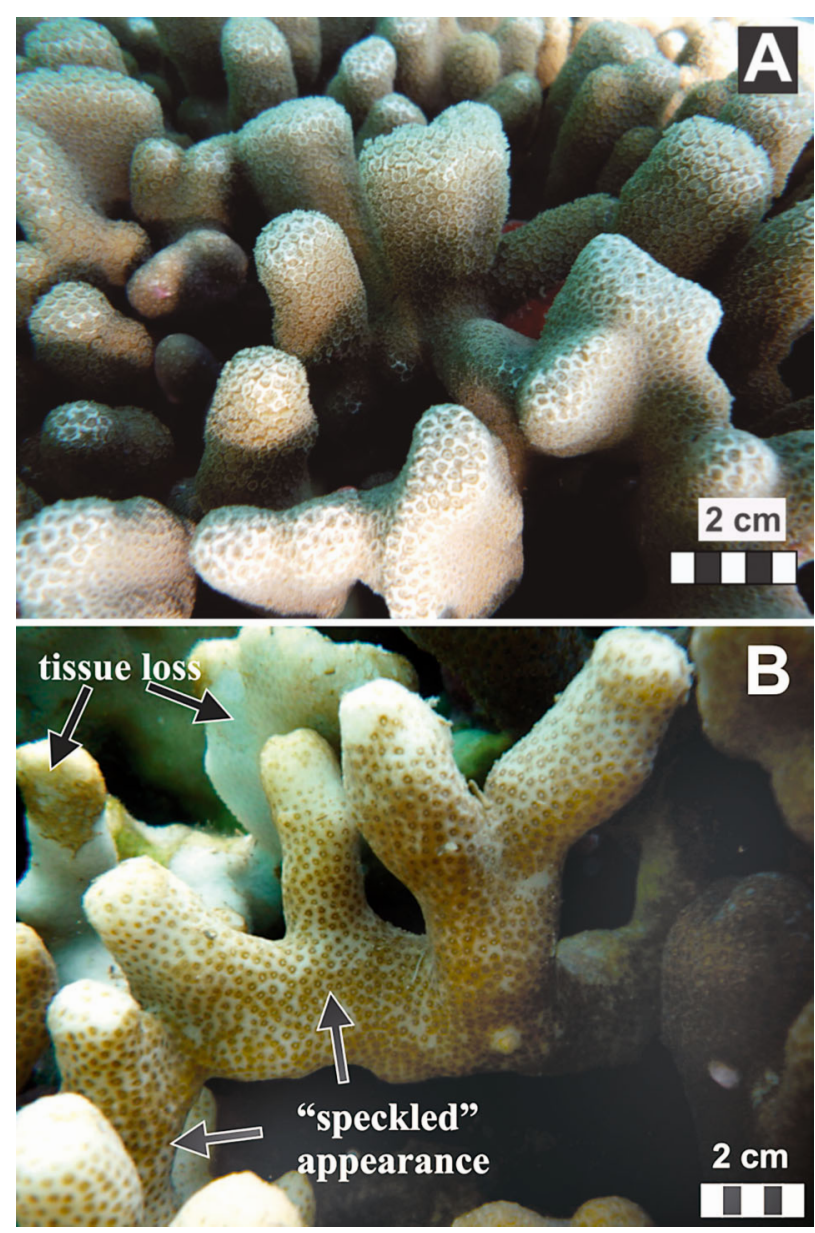

Fig. 1. (A) Healthy Porites compressa. Note regular brown coloration. (B) Porites bleaching with tissue loss (PBTL)affected $P$. compressa. Note pigmented polyps and bleached coenenchyme ('speckled appearance') with onset of tissue loss

proximately monthly basis during 2011. Five $10 \times 2 \mathrm{~m}$ belt transects were deployed at each site in which every Porites compressa colony was counted and examined for signs of PBTL.

To investigate the larger spatial extent of PBTL, rapid visual surveys were conducted on 9 patch reefs within Kaneohe Bay and on the reef in Hanuama Bay Marine Reserve (Fig. 2). Within Kaneohe Bay, a snorkeler swam for $10 \mathrm{~min}$ at a speed of approximately $10 \mathrm{~m} \mathrm{~min}^{-1}$ along a haphazardly selected patch reef and recorded every PBTL-affected colony observed. In Hanauma Bay, 2 divers swam across the reef at approximately the same speed and recorded the number of PBTL-affected colonies encountered within $30 \mathrm{~min}$. This rapid survey method allows a larger spatial coverage of the reefs and provides a semi-quantitative measure of disease abundance. All rapid surveys were conducted in October 2011.

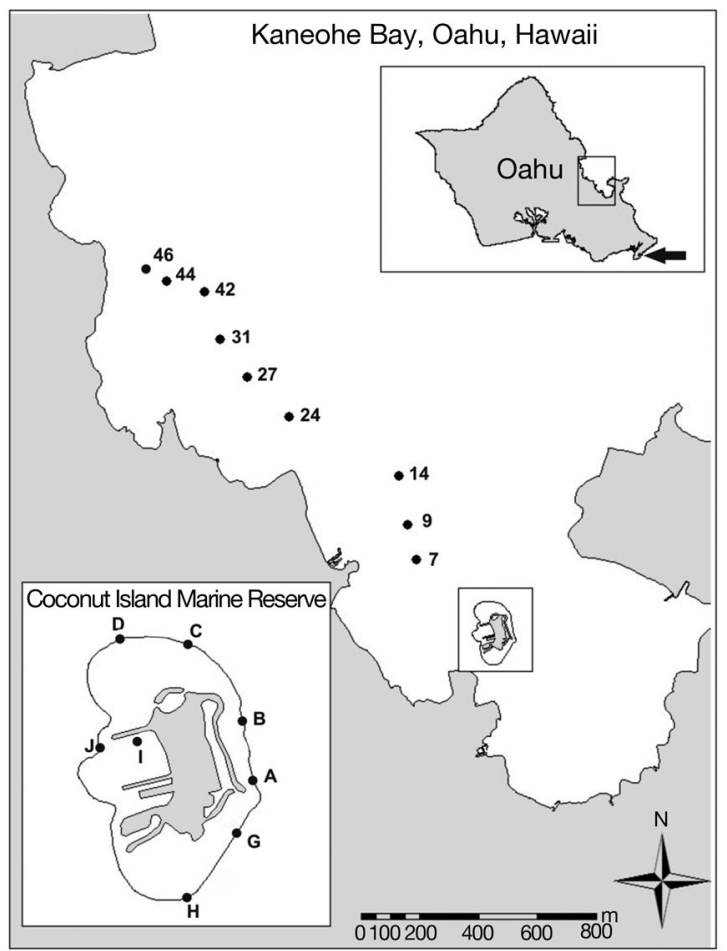

Fig. 2. Kaneohe Bay, Hawaii (USA), showing the 9 rapid survey sites (black dots marked 7 to 46 ) numbered after Roy (1970), with an inset of Oahu showing the location of Kaneohe Bay and Hanauma Bay (arrow) and another inset of Coconut Island Marine Reserve (CIMR) showing the 8 permanent sites (A-J)

\section{Disease virulence}

To determine disease virulence, 42 individual PBTL-affected colonies were tagged in 2010 (Sudek et al. 2012a), and an additional 36 PBTL-affected colonies were tagged in 2011 and followed through time (approximately monthly examinations). The colonies that were tagged in 2010 were resurveyed and checked for new PBTL signs and/or signs of tissue recovery. Due to the 3-dimensional structure of Porites compressa and the often poor visibility in Kaneohe Bay, we could not rely on photographic surveys with post hoc image analysis. Instead, the percentage of healthy, dead, and affected tissue was estimated visually in situ in addition to photo documentation.

\section{Transmission}

To determine whether PBTL is transmissible through the water column or via direct contact, healthy as well as PBTL-affected coral samples (approximately 
$3 \mathrm{~cm}^{2}$ each) were collected from the reef crest around CIMR using a bone cutter. Samples were transported to the lab in individual plastic bags to avoid any cross contamination. Manipulative experiments were run in aquaria (8 l) under closed conditions. To maintain water quality, a bubbler was placed in each aquarium to ensure water movement, and partial water changes, using $0.2 \mu \mathrm{m}$ filtered seawater, were carried out every $5 \mathrm{~d}$. Aquaria were kept outside under natural light.

To conduct the transmission experiment, a coral fragment showing signs of PBTL was placed in an aquarium touching a healthy fragment, with another fragment from the same healthy colony placed about $10 \mathrm{~cm}$ away from the PBTL-affected fragment $(\mathrm{n}=$ 10). As a control for possible effects of intraspecific competition, the same setup was used with fragments from the same healthy colony as those used in the transmission treatment, but the diseased fragment was replaced by a healthy fragment from a different colony $(\mathrm{n}=10)$. The healthy fragments were monitored daily for signs of PBTL over the course of at least 3 wk or until the affected fragment died (max. $5 \mathrm{wk}$ ). The transmission experiment was carried out at ambient $\left(25^{\circ} \mathrm{C}\right)$ and increased $\left(28^{\circ} \mathrm{C}\right)$ water temperatures to determine whether transmission would occur more readily at higher temperatures $(\mathrm{n}=10$ treatment ${ }^{-1}$ ). Thermal bleaching of Hawaiian corals occurs with prolonged exposure to $29-30^{\circ} \mathrm{C}$ (Jokiel \& Coles 1990), so by choosing a temperature of $28^{\circ} \mathrm{C}$, the experimental setup stayed below the range in which temperature-induced bleaching would usually occur. Additionally, the 'speckled' appearance of PBTL is not observed during thermal bleaching or bleaching due to competition; therefore only the typical 'speckled' bleaching appearance was considered a sign of PBTL.

\section{Environmental drivers}

All measurements of environmental variables were conducted at the depths of the transects. Temperature data were collected at each site using $\mathrm{HOBO}{ }^{\circledR}$ Pro data loggers (www.onsetcomp.com) with an accuracy of $\pm 0.2^{\circ} \mathrm{C}$. The loggers recorded continuously every 30 min from late February to late December 2011. Turbidity, chlorophyll a (chl a), and salinity were measured at each site using an $\mathrm{RBR}^{\circledR} \mathrm{XR}-420$ data logger (www.rbr-global.com) recording every minute over a 36 to $48 \mathrm{~h}$ period on 4 to 6 different occasions per site in 2010 and 2011. The logger was moved randomly between sites to maximize spatial coverage over time. Water motion was estimated using the clod card technique (Jokiel \& Morrissey 1993). Two clod cards were placed at the beginning of each survey site and left overnight (21 to $23 \mathrm{~h}$ ). In addition, 2 clod cards were placed into a large bucket containing seawater (ca. $60 \mathrm{l}$ ) to serve as a diffusion control. The exact time that the clod cards were immersed in water was recorded, and the diffusion factor (DF, a dimensionless index of water motion) was calculated for each site (Jokiel \& Morrissey 1993). Clod cards were deployed 4 times over the course of 6 mo in 2011, and the average DF for each site was used in subsequent data analyses.

Corallivorous fish can be potential vectors of disease (Aeby \& Santavy 2006) or a source of injury which can promote the spread of certain diseases (Page \& Willis 2008, Raymundo et al. 2009). The densities of all corallivorous butterflyfish (facultative and obligate) and parrotfish were recorded over an area of $50 \times 4 \mathrm{~m}$ at all 8 sites. The observer swam at a speed of approximately $10 \mathrm{~m} \mathrm{~min}^{-1}$ and recorded all butterflyfish to species level (Chaetodon auriga, $C$. ephippium, C. lineolatus, C. lunulatus, C. multicinctus, C. ornatissimus, C. unimaculatus). Due to difficulties with species-level identification, all parrotfish (adults and juveniles) were grouped. Fish counts were carried out during 4 different months in 2011 (July, August, September, December), and all sites were surveyed on the same day within 2 to $3 \mathrm{~h}$ of each other. Total numbers of fish were used in the subsequent data analyses.

\section{Statistical analyses}

Prevalence and spatial distribution

Prevalence data by transect did not display a normal distribution, even after transformation. We therefore used a repeated measures permutational analysis of variance based on a binomial deviance matrix (the technique does not assume normality) in PERMANOVA+ (Anderson et al. 2008), to test the effect of 2 fixed factors (site, month) and their interaction with disease prevalence.

\section{Environmental drivers}

To investigate temporal variations in disease prevalence, the relationship of temperature and prevalence was explored over a period of 10 mo using a general linear model (GLM) performed with SPSS 
(PASW 18). Prevalence was averaged for each site (over the 5 individual transects), and the data displayed a normal distribution. Temperature data were averaged over the $10 \mathrm{~d}$ period before each survey for every site.

To examine spatial variations in disease prevalence (differences in PBTL prevalence across sites regardless of month), 8 environmental predictor variables were modeled against spatial variations in prevalence across sites. Measurements for predictor variables were not continuous through time and were therefore averaged for each site. To achieve the same resolution for temperature and prevalence data, all temperature data (10 d before each survey) and prevalence values (February to December) were averaged for each site. Predictor variables were: host cover, turbidity, water temperature, chl $a$, water motion, salinity, parrotfish density, and butterflyfish density (Table 1). Because most butterflyfish species showed low abundances on the reef, all butterflyfish counts were grouped. The mean and 1 SD of all predictor variables were initially examined to also account for the variability of factors at the individual sites. Inter-correlation of predictor variables was tested using Pearson's correlation, with predictors exceeding a correlation value of $>0.75$ considered for removal and further examined using principal coordinates analysis (PCO) plots (Anderson et al. 2008). Variables chosen for inclusion in the model were mean values for host cover, temperature, chl $a$, and water motion, and the variability (SD) in turbidity, salinity, butterflyfish density, and parrotfish density. A permutational distance-based linear model (DISTLM) was used (McArdle \& Anderson 2001) to analyze the data. DISTLM is a multivariate multiple regression technique that quantifies the proportion of the variation in the response variable (in this case

Table 1. Predictor variables used in model analyses with their units and minimum and maximum values

\begin{tabular}{|llcc|}
\hline Variable & Description and units & Min. & Max. \\
\hline Water temp. & ${ }^{\circ} \mathrm{C}$ & 22.1 & 28.3 \\
Host cover & $\%$ Porites compressa cover & 30.0 & 75.6 \\
Turbidity & Formazin turbidity unit (FTU) & 0.3 & 22.6 \\
Chl a & $\mu \mathrm{g} \mathrm{l}^{-1}$ & 0.02 & 2.1 \\
Water motion & Diffusion factor (DF) & 1.26 & 7.95 \\
Salinity & ppt & 33.0 & 35.7 \\
Parrotfish & Number per $200 \mathrm{~m}^{2}$ & 0 & 68 \\
density & & & \\
Butterflyfish & Number per $200 \mathrm{~m}^{2}$ & 0 & 13 \\
density & & & \\
\hline
\end{tabular}

PBTL prevalence) explained by the predictor variables. Environmental data were normalized and the DISTLM routine was run using the 'best' selection procedure, based on 9999 permutations. Akaike's information criterion (Akaike 1973) with a secondorder bias correction applied (AICc) (Hurvich \& Tsai 1989, Burnham \& Anderson 2004) was used for model selection. The most parsimonious model with the lowest AICc and highest $\mathrm{R}^{2}$ value was selected. Modeling analyses were based on 0-adjusted Bray-Curtis similarity matrices (Clarke et al. 2006) and carried out using PRIMER v6 (Clarke \& Gorley 2006) and PERMANOVA+ (Anderson et al. 2008).

\section{RESULTS}

\section{Prevalence and spatial distribution}

Overall, average PBTL prevalence at CIMR was $1.5 \% \quad( \pm 0.2 \%$ SE $)$. PBTL-affected colonies were found at all 8 survey sites, but prevalence differed significantly between sites ( $\mathrm{df}=7$, pseudo- $F=9.5969$, $\mathrm{p}<0.001$; Fig. 3A) and between months ( $\mathrm{df}=9$, pseudo- $F=8.5552, \mathrm{p}<0.001$; Fig. 3B), but no significant interaction between the two was detected $(\mathrm{df}=$ 63 , pseudo- $F=0.83471, \mathrm{p}=0.7473$ ). PBTL-affected colonies were observed throughout the year, with a peak during the summer months (Fig. 3B) and the highest average prevalence observed in June $(2.5 \pm$ $0.3 \%$ SE). Rapid visual surveys showed that PBTL was present in all of Kaneohe Bay but that it was absent from Hanauma Bay (Table 2).

\section{Disease virulence and transmission}

Most colonies affected by PBTL showed the typical 'speckled' bleaching for a period of approximately 2 to 3 mo and then the disease regressed in most cases (no more signs of bleaching). Within this time, the majority of colonies ( $85 \%$ ) showed tissue loss ranging from 5 to $100 \%$ of the colony, with a case fatality rate (total mortality) of $3 \%$. On average, a colony lost a third $(30 \%)$ of its tissue within 2 mo. Of the 42 colonies tagged in 2010, $55 \%$ showed no signs of recovery in 2011, and $24 \%$ showed partial tissue regrowth. In addition, $31 \%$ of these colonies became affected again by PBTL during 2011.

No disease transmission occurred between individuals via the water column or direct contact in either the ambient or the increased temperature treatments $\left(\mathrm{n}=10\right.$ treatment $\left.^{-1}\right)$. 


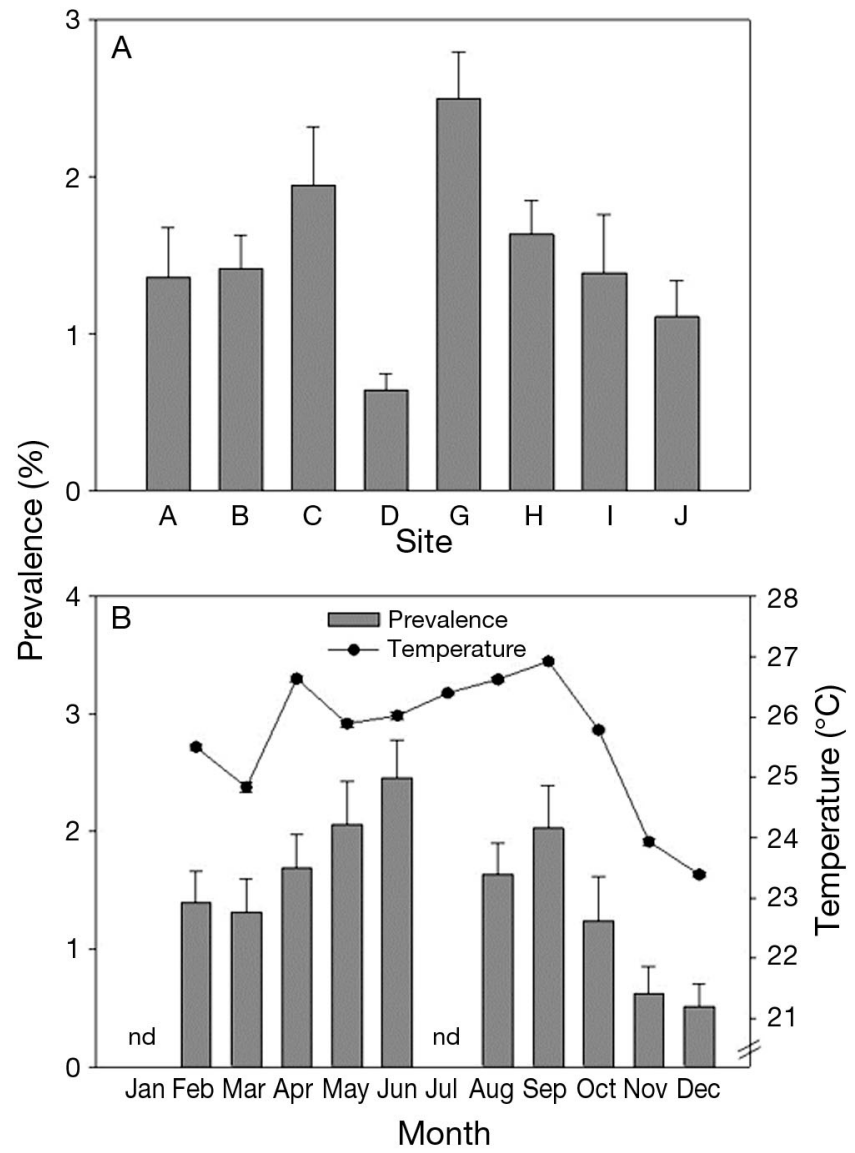

Fig. 3. Porites bleaching with tissue loss (PBTL) prevalence at Coconut Island Marine Reserve (CIMR). (A) Average prevalence $( \pm \mathrm{SE})$ for each permanent site around CIMR. (B) Average prevalence over sites $( \pm$ SE) for each month in 2011 with corresponding average temperature (the average over $10 \mathrm{~d}$ prior to surveying); nd: no prevalence data obtained

Table 2. Number of Porites bleaching with tissue loss (PBTL)-affected Porites compressa colonies observed (see Fig. 1 for reef locations) during rapid surveys within Kaneohe Bay and Hanauma Bay, Hawaii, USA

\begin{tabular}{|lcc|}
\hline Area & $\begin{array}{c}\text { Reef } \\
\text { no. }\end{array}$ & $\begin{array}{c}\text { No. of colonies min } \\
\text { of search time }\end{array}$ \\
\hline Kaneohe Bay & & \\
North Bay & 46 & 1.6 \\
& 44 & 2.4 \\
Central Bay & 43 & 1.9 \\
& 31 & 1.2 \\
South Bay & 27 & 3.0 \\
& 24 & 2.1 \\
SE Oahu & 14 & 2.4 \\
& 9 & 2.5 \\
& Hanauma Bay & 0.8 \\
\hline
\end{tabular}

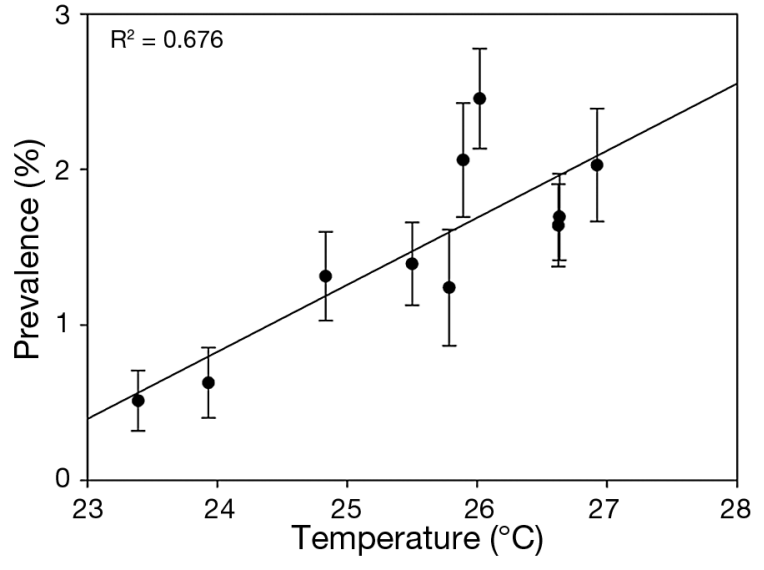

Fig. 4. Relationship of average Porites bleaching with tissue loss (PBTL) prevalence $( \pm \mathrm{SE})$ for each month (February to December) with corresponding temperature (the average over $10 \mathrm{~d}$ prior to surveying)

\section{Environmental drivers}

A significant positive linear relationship was found between temporal water temperature and disease prevalence (GLM: Wald $\chi^{2}=38.128$, df = 1, p < 0.001; Fig. 4). Based on this relationship, each degree increase in temperature can be expected to result in an increase of 0.29 to $0.56 \%$ in disease prevalence.

Modeling of the spatial variation in PBTL prevalence across sites identified water motion and the variability in turbidity and parrotfish density as the strongest predictors, with $26.2 \%$ of the total variability in PBTL prevalence across sites explained (Table 3). Water motion and parrotfish density showed a positive correlation to variations in PBTL prevalence, whereas turbidity showed a weak negative correlation. Butterflyfish density, chl $a$, spatial temperature (difference between sites), salinity, and host cover were not found to be important spatial predictors of PBTL prevalence across sites.

\section{DISCUSSION}

\section{Prevalence and distribution}

PBTL was found to be widely distributed on reefs within Kaneohe Bay but was absent from Hanauma Bay which also has a high abundance of the affected coral species (Porites compressa). PBTL has also not been reported from other reefs within the Main or Northwestern Hawaiian Islands (Aeby et al. 2011a), 
Table 3. Summary results of a distance-based linear model (DISTLM) analysis showing the 'best' model with the lowest Akaike's information criterion with a second-order bias correction (AICc) value and highest amount of variability explained

\begin{tabular}{|llcccc|}
\hline \multirow{2}{*}{ AICc } & Predictor & Pseudo- $F$ & $\mathrm{p}$ & \% variability explained & Relationship with prevalence \\
\hline 274.94 & Turbidity SD & 6.0364 & 0.0026 & 12.8 & Negative \\
& Water motion & 3.7671 & 0.0281 & 9.0 & Positive \\
& Parrotfish density SD & 2.1351 & 0.1148 & 4.4 & Positive \\
& & & $\mathbf{2 6 . 2}$ & \\
\hline
\end{tabular}

suggesting that PBTL may be restricted to Kaneohe Bay.

In Hawaii, average coral disease prevalence (excluding Porites trematodiasis) is less than 1\% (Aeby et al. 2011a), which is lower than what was documented for PBTL (average prevalence: $1.5 \pm 0.2 \%$ $\mathrm{SE}$; range: 0 to $3.7 \%$ ). Compared to other diseases within Kaneohe Bay, PBTL prevalence was higher than that of MWS (average prevalence: $0.23 \pm 0.09 \%$ SE; Aeby et al. 2010) but lower than Porites growth anomalies (Por GAs) (average prevalence: $21.7 \pm$ $8.3 \%$ SE at a particular site; Domart-Coulon et al. 2006). However, both MWS and Por GAs have a wider range in prevalence across sites within Kaneohe Bay (0 to 29 and 1 to $56 \%$, respectively) (Williams et al. 2010).

The ecological damage from disease on a host population depends on a combination of the spatial distribution, prevalence, and virulence of the disease. For example, MWS has a much lower prevalence than Por GAs, but MWS can cause extensive tissue loss and high colony mortality (Aeby et al. 2010), whereas Por GAs only result in colony morbidity (reduced growth) (Stimson 2011). PBTL has a relatively low prevalence, but it can cause extensive tissue loss, and recovery rates (tissue re-growth) appear to be very slow. It was found to be an ephemeral disease with disease signs (speckled bleaching) disappearing in most cases within a couple of months, and a small proportion of colonies showed disease regression (i.e. repigmentation) without any signs of tissue loss. However, a third of the colonies showed signs of PBTL again after complete cessation of the disease. A number of other coral diseases have also been found to reoccur (e.g. Kuta \& Richardson 1996, Sato et al. 2009, Aeby et al. 2010), and it has been suggested that recurrent infections can cause cumulative tissue loss leading to colony mortality and resulting in increased damage to the reef system over time (Borger \& Steiner 2005). Even though PBTL prevalence is relatively low, a cumulative effect of periodic tissue loss could have a negative impact on Porites compressa-dominated reefs.

\section{Transmission}

No disease transmission was observed between healthy and PBTL-affected fragments, suggesting that PBTL does not easily transmit via direct contact or the water column (at least over a period of approximately 1 to $2 \mathrm{mo}$ ). It may be that the environmental conditions needed for successful transmission were not replicated by our experimental treatment. However, direct transmission between touching colonies was also not observed in the field. In contrast, other manipulative experiments have successfully shown disease transmission in aquaria. For example, MWS was shown to be transmissible through direct contact in aquarium conditions, with direct transmission also observed in the field (Aeby et al. 2010). In our model, we found that host abundance was not an important factor in predicting PBTL prevalence. The relationship between disease prevalence and host abundance is a central element in the theory of infectious disease ecology (Lloyd-Smith et al. 2005) because transmission is a key process in host-pathogen interactions, and increased host density can increase the probability of horizontal transmission of an infectious disease (Altizer \& Augustin 1997). As such, we suggest that PBTL is either not caused by a pathogen, is not highly infectious, or that some other variable, such as a vector, may be needed for disease transmission.

\section{Environmental drivers}

Variations in turbidity were identified as the overall strongest predictor of spatial variation in disease prevalence (higher PBTL prevalence) across sites. Turbidity showed a weak negative relationship with PBTL prevalence, indicating that clearer waters are associated with higher disease prevalence. We also found that PBTL prevalence, across all sites, was highest during the summer months, strongly correlated with water temperature. Increased disease prevalence on coral reefs often correlates with ele- 
vated seawater temperature, for example as reported for BBD (Boyett et al. 2007, Rodriguez \& Croquer 2008), some white syndromes (Selig et al. 2006, Bruno et al. 2007, Williams et al. 2010, 2011a), and a fungal disease affecting tropical crustose coralline algae (Williams et al. 2014). Increased temperatures can lead to an increase in pathogen virulence and/or cause stress to the host, making it more susceptible to disease (Harvell et al. 2007). However, water temperature is not the only abiotic factor that varies seasonally on reefs. For example, Sato et al. (2011) found that high light and elevated seawater temperature drive the occurrence of BBD on the GBR. They proposed that seasonally increased light levels may be even more important for inducing new infections than increased water temperature. A link to increased light could explain the spotty appearance of PBTL (bleached coenenchyme and pigmented polyps), as Symbiodinium cells may be more shielded in the polyps because they can retract into the skeleton. However, manipulative experiments are needed to clarify the link between light, temperature, and PBTL.

PBTL prevalence was also correlated with higher water motion and higher parrotfish densities, although the link appeared rather weak and is therefore not discussed further. Overall, only a quarter of the variability in PBTL prevalence could be explained by the measured factors, suggesting that other unmeasured abiotic or biotic factors could be more important drivers of PBTL prevalence. Alternatively, our predictor variables may not have been captured at an appropriate temporal scale, with seasonal variations in these factors missed; this may have caused a reduction of the predictive power of our model. Cause of disease is dependent on the intricate interactions between the host, environment, and pathogen (Work et al. 2008). One can therefore expect coral disease spatio-temporal dynamics to be highly complex and to be correlated with multiple, and possibly co-interacting, environmental drivers (Williams et al. 2010).

\section{CONCLUSION}

This is the first study examining the disease dynamics of PBTL in Kaneohe Bay, Hawaii. PBTL causes partial colony mortality in the host coral Porites compressa, appears to be non-infectious, and was found to have the highest prevalence occurring in the warmer summer months, indicating possible seasonal dynamics. Spatial variation in disease prevalence (higher PBTL prevalence) across sites was correlated with higher water motion, lower turbidity, and higher parrotfish densities, but the model did not sufficiently explain the spatial variability. This highlights the complex nature of host-pathogen-environment interactions and the need for investigating and understanding coral disease ecology. Further research into the causative agent and links to environmental drivers, specifically at a finer temporal scale, are needed to better understand the dynamics of this disease. Porites compressa is among the main framework-building corals in Kaneohe Bay, and so chronic, recurrent diseases, such as PBTL, could have a negative impact on the health and structure of these reefs.

Acknowledgements. We thank all field assistants for their dedicated help, Timothy Jones for advice on the GLM, and Jamie Sziklay for assistance in constructing the site map. M.S. was supported by a VUW PhD Scholarship. Coral collection was authorized under Special Activity Permit (SAP) 2011-67.

\section{LITERATURE CITED}

Aeby GS (2007) Spatial and temporal patterns of Porites trematodiasis on the reefs of Kaneohe Bay, Oahu, Hawaii. Bull Mar Sci 80:209-218

Aeby GS, Santavy DL (2006) Factors affecting susceptibility of the coral Montastraea faveolata to black-band disease. Mar Ecol Prog Ser 318:103-110

Aeby GS, Ross M, Williams GJ, Lewis TD, Work TM (2010) Disease dynamics of Montipora white syndrome within Kaneohe Bay, Oahu, Hawaii: distribution, seasonality, virulence, and transmissibility. Dis Aquat Org 91:1-8

Aeby GS, Williams GJ, Franklin EC, Kenyon J, Cox EF, Coles S, Work TM (2011a) Patterns of coral disease across the Hawaiian Archipelago: relating disease to environment. PLoS ONE 6:e20370

Aeby GS, Williams GJ, Franklin EC, Haapkylä J and others (2011b) Growth anomalies on the coral genera Acropora and Porites are strongly associated with host density and human population size across the Indo-Pacific. PLoS ONE 6:e16887

Akaike H (1973) Information theory as an extension of the maximum likelihood principal. Proceedings 2nd International Symposium of Information Theory. Akademic Kiado, Budapest, p 261-281

> Altizer SM, Augustin DJ (1997) Interactions between frequency-dependent and vertical transmission in host-parasite systems. Proc R Soc Lond B Biol Sci 264:807-814

Anderson MJ, Gorley RN, Clarke KR (2008) PERMANOVA+ for PRIMER: guide to software and statistical methods. PRIMER-E, Plymouth

Aronson RB, Precht WF (2001) White-band disease and the changing face of Caribbean coral reefs. Hydrobiologia 460:25-38

Borger JL, Steiner SCC (2005) The spatial and temporal dynamics of coral diseases in Dominica, West Indies. Bull Mar Sci 77:137-154

Boyett HV, Bourne DG, Willis BL (2007) Elevated tempera- 
ture and light enhance progression and spread of black band disease on staghorn corals of the Great Barrier Reef. Mar Biol 151:1711-1720

Bruckner AW, Hill RL (2009) Ten years of change to coral communities off Mona and Desecheo Islands, Puerto Rico, from disease and bleaching. Dis Aquat Org 87: 19-31

Bruckner AW, Bruckner RJ, Williams EH (1997) Spread of a black-band disease epizootic through the coral reef system in St. Ann's Bay, Jamaica. Bull Mar Sci 61:919-928

Bruno JF, Petes LE, Harvell CD, Hettinger A (2003) Nutrient enrichment can increase the severity of coral diseases. Ecol Lett 6:1056-1061

Bruno JF, Selig ER, Casey KS, Page CA and others (2007) Thermal stress and coral cover as drivers of coral disease outbreaks. PLoS Biol 5:e124

> Burnham KP, Anderson DR (2004) Multimodel inferenceunderstanding AIC and BIC in model selection. Sociol Methods Res 33:261-304

Clarke KR, Gorley RN (2006) PRIMER v6: user manual/tutorial. Primer-E, Plymouth

> Clarke KR, Somerfield PJ, Chapman MG (2006) On resemblance measures for ecological studies, including taxonomic dissimilarities and a zero-adjusted Bray-Curtis coefficient for denuded assemblages. J Exp Mar Biol Ecol 330:55-80

Croquer A, Weil E, Zubillaga AL, Pauls SM (2005) Impact of a white plague-II outbreak on a coral reef in the archipelago Los Roques National Park, Venezuela. Caribb J Sci 41:815-823

> Domart-Coulon IJ, Traylor-Knowles N, Peters E, Elbert D and others (2006) Comprehensive characterization of skeletal tissue growth anomalies of the finger coral Porites compressa. Coral Reefs 25:531-543

Edmunds PJ (1991) Extent and effect of black band disease on a Caribbean reef. Coral Reefs 10:161-165

Gladfelter WB (1982) White band disease in Acropora palmata-implications for the structure and growth of shallow reefs. Bull Mar Sci 32:639-643

> Haapkylä J, Seymour AS, Trebilco J, Smith D (2007) Coral disease prevalence and coral health in the Wakatobi Marine Park, south-east Sulawesi, Indonesia. J Mar Biol Assoc UK 87:403-414

Harvell CD, Kim K, Burkholder JM, Colwell RR and others (1999) Emerging marine diseases - climate links and anthropogenic factors. Science 285:1505-1510

Harvell CD, Mitchell CE, Ward JR, Altizer S, Dobson AP, Ostfeld RS, Samuel MD (2002) Climate warming and disease risks for terrestrial and marine biota. Science 296: 2158-2162

> Harvell D, Aronson R, Baron N, Connell J and others (2004) The rising tide of ocean diseases: unsolved problems and research priorities. Front Ecol Environ 2:375-382

Harvell D, Jordan-Dahlgren E, Merkel S, Rosenberg E and others (2007) Coral disease, environmental drivers, and the balance between coral and microbial associates. Oceanography 20:172-195

> Hurvich CM, Tsai CL (1989) Regression and time-series model selection in small samples. Biometrika 76:297-307

> Jokiel PL, Coles SL (1990) Response of Hawaiian and other Indo-Pacific reef corals to elevated temperature. Coral Reefs 8:155-162

> Jokiel PL, Morrissey JI (1993) Water motion on coral reefs: evaluation of the 'clod card' technique. Mar Ecol Prog Ser 93:175-181
Kaczmarsky LT (2006) Coral disease dynamics in the central Philippines. Dis Aquat Org 69:9-21

Kuta KG, Richardson LL (1996) Abundance and distribution of black band disease on coral reefs in the northern Florida Keys. Coral Reefs 15:219-223

Lafferty KD, Kuris AM (1993) Mass mortality of abalone Haliotis cracherodii on the California Channel Islands: tests of epidemiological hypotheses. Mar Ecol Prog Ser 96:239-248

> Lafferty KD, Porter JW, Ford SE (2004) Are diseases increasing in the ocean? Annu Rev Ecol Evol Syst 35:31-54

Lessios HA (1988) Mass mortality of Diadema antillarum in the Caribbean: What have we learned? Annu Rev Ecol Syst 19:371-393

- Lloyd-Smith JO, Cross PC, Briggs CJ, Daugherty M and others (2005) Should we expect population thresholds for wildlife disease? Trends Ecol Evol 20:511-519

McArdle BH, Anderson MJ (2001) Fitting multivariate models to community data: a comment on distance-based redundancy analysis. Ecology 82:290-297

McClanahan TR, Weil E, Maina J (2009) Strong relationship between coral bleaching and growth anomalies in massive Porites. Glob Change Biol 15:1804-1816

Nugues MM (2002) Impact of a coral disease outbreak on coral communities in St. Lucia: What and how much has been lost? Mar Ecol Prog Ser 229:61-71

Page C, Willis B (2006) Distribution, host range and largescale spatial variability in black band disease prevalence on the Great Barrier Reef, Australia. Dis Aquat Org 69: $41-51$

Page CA, Willis BL (2008) Epidemiology of skeletal eroding band on the Great Barrier Reef and the role of injury in the initiation of this widespread coral disease. Coral Reefs 27:257-272

Patterson KL, Porter JW, Ritchie KE, Polson SW and others (2002) The etiology of white pox, a lethal disease of the Caribbean elkhorn coral, Acropora palmata. Proc Natl Acad Sci USA 99:8725-8730

Raymundo LJ, Rosell KB, Reboton CT, Kaczmarsky L (2005) Coral diseases on Philippine reefs: genus Porites is a dominant host. Dis Aquat Org 64:181-191

Raymundo LJ, Halford AR, Maypa AP, Kerr AM (2009) Functionally diverse reef fish communities ameliorate coral disease. Proc Natl Acad Sci USA 106:17067-17070

> Rodriguez S, Croquer A (2008) Dynamics of black band disease in a Diploria strigosa population subjected to annual upwelling on the northeastern coast of Venezuela. Coral Reefs 27:381-388

Roff G, Hoegh-Guldberg O, Fine M (2006) Intra-colonial response to Acroporid 'white syndrome' lesions in tabular Acropora spp. (Scleractinia). Coral Reefs 25:255-264

Roy KJ (1970) Change in bathymetric configuration, Kaneohe Bay, Oahu, 1882-1969. Hawaii Institute of Geophysics, University of Hawaii, Honolulu, HI

Sato Y, Bourne DG, Willis BL (2009) Dynamics of seasonal outbreaks of black band disease in an assemblage of Montipora species at Pelorus Island (Great Barrier Reef, Australia). Proc R Soc Lond B Biol Sci 276:2795-2803

Sato Y, Bourne DG, Willis BL (2011) Effects of temperature and light on the progression of black band disease on the reef coral, Montipora hispida. Coral Reefs 30:753-761

Selig E, Harvell C, Bruno J, Willis B, Page C, Casey K, Sweatman H (2006) Analyzing the relationship between ocean temperature anomalies and coral disease outbreaks at broad spatial scales. In: Phinney J, Hoegh- 
Guldberg O, Kleypas J, Skirving W, Strong A (eds) Coral reefs and climate change: science and management. Coastal and estuarine studies. American Geophysical Union, Washington DC, p 111-128

Sokolow S (2009) Effects of a changing climate on the dynamics of coral infectious disease: a review of the evidence. Dis Aquat Org 87:5-18

Stimson J (2011) Ecological characterization of coral growth anomalies on Porites compressa in Hawai'i. Coral Reefs 30:133-142

Sudek M, Aeby GS, Davy SK (2012a) Localized bleaching in Hawaii causes tissue loss and a reduction in the number of gametes in Porites compressa. Coral Reefs 31:351-355

Sudek M, Work TM, Aeby GS, Davy SK (2012b) Histological observations in the Hawaiian reef coral, Porites compressa, affected by Porites bleaching with tissue loss (PBTL). J Invertebr Pathol 111:121-125

Sutherland KP, Porter JW, Torres C (2004) Disease and immunity in Caribbean and Indo-Pacific zooxanthellate corals. Mar Ecol Prog Ser 266:273-302

Vargas-Angel B (2009) Coral health and disease assessment in the US Pacific remote island areas. Bull Mar Sci 84: 211-227

Ward JR, Lafferty KD (2004) The elusive baseline of marine disease: Are diseases in ocean ecosystems increasing? PLoS Biol 2:e120

Editorial responsibility: Garriet Smith, Aiken, South Carolina, USA
Williams GJ, Davy SK, Aeby GS (2008) Coral disease at Palmyra Atoll, a remote reef system in the Central Pacific. Coral Reefs 27:207

- Williams GJ, Aeby GS, Cowie ROM, Davy SK (2010) Predictive modeling of coral disease distribution within a reef system. PLoS ONE 5:e9264

> Williams GJ, Knapp IS, Work TM, Conklin EJ (2011a) Outbreak of Acropora white syndrome following a mild bleaching event at Palmyra Atoll, Northern Line Islands, Central Pacific. Coral Reefs 30:621

Williams GJ, Knapp IS, Aeby GS, Davy SK (2011b) Spatial and temporal patterns of scleractinian coral, soft coral and zoanthid disease on a remote, near-pristine coral reef (Palmyra Atoll, central Pacific). Dis Aquat Org 94: 89-100

Williams GJ, Price NN, Ushijima B, Aeby GS and others (2014) Ocean warming and acidification have complex interactive effects on the dynamics of a marine fungal disease. Proc R Soc Lond B Biol Sci 281:20133069

Willis BL, Page CA, Dinsdale EA (2004) Coral disease on the Great Barrier Reef. In: Rosenberg E, Loya Y (eds) Coral health and disease. Springer, Berlin, p 69-104

> Work TM, Richardson LL, Reynolds TL, Willis BL (2008) Biomedical and veterinary science can increase our understanding of coral disease. J Exp Mar Biol Ecol 362: 63-70

Submitted: June 3, 2014; Accepted: November 11, 2014 Proofs received from author(s): January 28, 2015 